\title{
Biosaintifika
}

Journal of Biology \& Biology Education

http://journal.unnes.ac.id/nju/index.php/biosaintifika

\section{Okra Polysaccharides Improves Spleen Weight and B-Lymphocytes Proliferation in Mice Infected by Staphylococcus aureus}

\author{
${ }^{\square}$ Sri Puji Astuti Wahyuningsih, Manikya Pramudya, Intan Permata Putri, Nadyatul \\ Ilma Indah Savira, Dwi Winarni, Listijani Suhargo, Win Darmanto
}

DOI: 10.15294/biosaintifika.v9i3.11284

Department of Biology, Faculty of Science and Technology, Universitas Airlangga, Indonesia

\section{History Article}

Received 29 September 2017 Approved 26 November 2017 Published 31 December 2017

\section{Keywords}

B-lymphocytes proliferation; Immunomodulatory activity; Okra polysaccharides; Spleen weight

\begin{abstract}
Okra (Abelmoschus esculentus) is reported to have various biological functions such as antioxidant, anticancer and anti-inflammation. However, only few studies have been reported immunomodulatory activities of okra to prevent disease caused by bacteria infection. In this study, the immunomodulatory activities of polysaccharides from okra pods were investigated further through the spleen weight and B-lymphocytes proliferation in mice infected by Staphylococcus aureus. Okra polysaccharides were obtained by water extraction and ethanol precipitation. Okra polysaccharides with doses of $25,50,75$, and $100 \mathrm{mg} / \mathrm{kg} \mathrm{BW}$ were orally administrated to mice with or without Staphylococcus aureus infection. Spleen weight was evaluated in both treatment group and control group. B-lymphocytes proliferation was evaluated by MTT assay using LPS induction. Results showed that okra polysaccharide at the doses of 50,75 , and $100 \mathrm{mg} / \mathrm{kg}$ increased spleen weight $(\mathrm{p}<0.05)$ significantly. While at the dose of 75 and $100 \mathrm{mg} / \mathrm{kg}$, it increased the B-lymphocytes proliferation $(\mathrm{p}<0.05)$ significantly. There is positive correlation between the spleen weight and B-lymphocytes proliferation by $73.3 \%$. These result reveal that okra polysaccharide could improve the immune response and be utilized as a novel candidate of neutraceutical.
\end{abstract}

\section{How to Cite}

Wahyuningsih, S. P. A., Pramudya, M., Putri, I. P., Savira, N. I. I., Winarni, D., Suhargo, L., \& Darmanto, W. (2017). Okra Polysaccharides Improves Spleen Weight and B-Lymphocytes Proliferation in Mice Infected by Staphylococcus aureus. Biosaintifika: Journal of Biology \& Biology Education, 9(3), 460-465.

(C) 2017 Universitas Negeri Semarang
Correspondence Author:

J1. Mulyorejo Kampus C Surabaya, 60115

E-mail: sri-p-a-w@fst.unair.ac.id
p-ISSN 2085-191X

e-ISSN 2338-7610 


\section{INTRODUCTION}

High demand of nutritional food is as high as the increase of knowledge about food for health. Nutraceutical product is any product derived from food sources that provides health and medical benefits. Nutraceutical product shoud act as an antioxidant, anti-inflammation, be able to improve immune system and prevent cancer (Bhowmik et al., 2013). On the other hand, human body is surrounded by environment contained microbes including extracellular bacteria such as Staphylococcus aureus. The bacteria is one of the main causes of nosocomial infections which can result in serious infections such as bacteremia, pneumonia and endocarditis (Diekema et al., 2001; Schito, 2006). From all infection cases in Indonesia, $7.1 \%$ was identified as nosocomial cases (World Health Organization, 2011)

In recent years, using immunomodulator to enhance the immune response has proven to be an effective way to increase resistance to disease (Zhao et al., 2014). Study conducted by Wahyuningsih et al. (2016) showed a significant increase of phagocytic activity in treatment group treated by polysaccharides from Coriolus versicolor. Polysaccharides from plants have been known as an important immunostimulatory agent with broad spectrum, low toxicity and few side effects (Cho et al., 2014). One of promising polysaccharides is the one derived from okra. Okra (Abelmoschus esculentus) is a flowering plant from Malvaceae family cultivated in tropical, subtropical and warm temperate regions around the world (Khatun et al., 2011; Naveed et al., 2009).Okra pods often were used as a traditional medicine for the treatment of gastric irritation and inflammation (Lim, 2012). The active compounds of okra are flavonoids and vitamine $C$ as antioxidant (Arapitsas, 2008; Lim, 2012). Meanwhile, okra polysaccharides acts were used as immunomodulator (Chen et al., 2016).

A study by Chen $e$ al. (2012) showed that okra polysaccharides increased spleen index, splenocytes proliferation, Interleukin (IL)-10 level, Tumor Necrosis Factor (TNF)- $\alpha$ level, and Interferon (IFN)- $\gamma$ level with cyclophosphamide as an antigen. Okra extract also modulated immune response by increasing IL-12 level (Sheu and Lai, 2012). According to Zheng et al. (2016), okra polysaccharides induced NO and cytokine production of mouse macrophage cell line RAW264.7. Okra fruit extract was also reported to have anti-adhesive activity against Helicobacter pylori, made rational basis for its use against gastric irritative and inflammatory diseases (Lengs- feld et al., 2007).

However, there was little report on okra consumption as immunomodulator for combating $S$. aureus infection. Hence the objective of the present study is to examine the immunomodulatory activities of okra after $S$. aureus infection based on spleen weight and B-lymphocytes proliferation. This research is conducted to reveal okra polysaccharides potention as alternative food that provides health and medical benefits in addition to the basic nutritional value found in foods.

\section{METHODS}

For preparation of okra polysaccharides, fresh okra pods $(500 \mathrm{~g})$ were mashed and macerated with $500 \mathrm{ml}$ of distilled water overnight three times. Supernatants were collected and centrifuged at $4300 \mathrm{rpm}$ for $5 \mathrm{~min}$. The supernatant was precipitated in absolute ethanol $1 \mathrm{X}$ sample volume, incubated for $24 \mathrm{~h}$ at $4^{\circ} \mathrm{C}$ and centrifuged. The pellet was dissolved in distilled water and centrifuged. The supernatant was collected and lyophilized (Chen et al., 2016).

Okra polysaccharides were administrated by gavage daily for 14 consecutive days. Male $\mathrm{BALB} / \mathrm{c}$ mice were randomly divided into six groups (5 for each group). Group $\mathrm{KN}$ was control, group $\mathrm{K}$ - was negative control which being exposed to $S$. aureus without okra polysaccharides administration, group P1, P2, P3 and P4 were administrated with okra polysaccharides at dose of $25 \mathrm{mg} / \mathrm{kg} \mathrm{BW}, 50 \mathrm{mg} / \mathrm{kg} \mathrm{BW}, 75 \mathrm{mg} / \mathrm{kg} \mathrm{BW}$, and $100 \mathrm{mg} / \mathrm{kg}$ BW respectively before being exposed to $S$. aureus. Mice were exposed to $S$. aureus ( 0.5 Mc. Farland) by means of intraperitoneal injection once, at $15^{\text {th }}$ day after okra administration. Two weeks after $S$. aureus infection, the mice were sacrificed by ketamine anesthesia $(0.1 \mathrm{ml}$ for each). The spleens were taken under aseptic condition. Spleens were cleaned from blood cloth and contaminating tissue. Each spleen weight was measured to evaluate the effect of polysaccharides in all groups. After that, spleens were placed in PBS-Penicillin-Streptomycin on ice.

To examine B-lymphocytes proliferation, spleen was placed in $10 \mathrm{~cm}$ of petridish containing $5 \mathrm{ml}$ of PBS, cut in small pieces and crushed using two sterile glass slides. The lymphocytes suspension was filtered through 200-mesh to collect a single suspension and centrifuged at 1000 rpm for $5 \mathrm{~min}$. Pellet was resuspended in Trisbuffered $\mathrm{NH}_{4} \mathrm{Cl}, \mathrm{pH} 7.2$ and centrifuged to lyse red blood cells. Previous step can be repeated again until the white pellet was obtained. Lymphocytes were washed with $5 \mathrm{ml}$ of PBS-Penicil- 
lin Streptomycin and resuspended in RPMI-1640 medium supplemented with FBS 10\%. Cells numbers were counted by haemocytometer. 195 $\mu 1$ of splenocytes $\left(3 \times 10^{5}\right.$ cells/well) and $5 \mu 1$ of LPS $(200 \mu \mathrm{g} / \mathrm{ml})$ were cultured in 96 well plates to induce B-lymphocytes proliferation. Plates were incubated at $37^{\circ} \mathrm{C}$ in incubator with $5 \% \mathrm{CO}_{2}$ for $48 \mathrm{~h} .50 \mu \mathrm{l}$ of MTT solution was added and incubated for $4 \mathrm{~h}$. The DMSO solution was added and incubated in incubator with $5 \% \mathrm{CO}_{2}$ for $1 \mathrm{~h}$. Absorbance was measured in microplate reader at $560 \mathrm{~nm}$.

Statistical analysis for spleen weight was performed by One-Way ANOVA test followed by Duncan test. Statistical analysis for B-lymphocytes proliferation was performed by Brown-Forsythe test followed by Games-Howell test. The results were presented as mean $\pm \mathrm{SD}$. $P$-values less than 0.05 considered statistically significant.

\section{RESULTS AND DISCUSSION}

Immune system protects organism against bacteria infection. Immune system is divided into innate immunity, which provides immediate protection against microbial invasion and adaptive immunity, which more slowly developed but provides more specialized defense against infections (Abbas et al., 2010). Immune system is a complex and important physiological system, which can cause various serious diseases when it out of balance. In the last few decades, many polysaccharide-protein complexes with immunomodulatory activity from medicinal herbs have become primary concern of researchers to prevent the disease (Schepetkin \& Quinn, 2006). Okra pods have long been used both as a food source and as traditional medicine for many disease (Chen $\mathrm{et}$ al., 2016). Okra (Abelmoschus esculentus) is a vegetable plant known as bendi in Malaysia, kra jeab khiew in Thailand, lender in Riau, or Arab nuts in West Kalimantan (Nadira et al., 2009). The active compound presented in okra are vitamin $\mathrm{C}$ and flavonoid in the form of oligomer catechin and quercetin (Arapitsas, 2008; Lim, 2012). Phenol compounds and vitamin $C$ have scavenger activity against free radicals (Battino et al., 1999). It was also reported that okra pods contain many polysaccharides (Arapitsas, 2008; Movin-Jesu, 2007). Polysaccharides from okra pods are receiving attention in the field of functional food and can be a novel nutraceutical in the future

Host defense gives different immune response due to an infection of intracellular and extracellular bacteria. Staphyloccoccus aureus is extracellular bacteria. Based on D'Elios et al. (2011), $S$. aureus will be recognized first by phagocytes such as macrophages and dendritic cell. Beside doing phagocytosis, activated phagocytes play a key role in presenting $S$. aureus to Helper T-lymphocytes (Th) naïve. The presence of presented $S$. aureus and cytokines produced by phagocytes induce the activation Th-17 cell. Then, Th-17 cells induce the differentiation of B-lymphocyte followed with antibody secretion to lyse $S$. aureus. Normally, immune system components such as macrophage, lymphocytes, natural killer cells, cytokines and complement will inhibit the transmission of $S$. aureus but these bacteria also release components against the immune system (Lin \& Peterson, 2010). Human body needs compound to enhance immune response.

Lymphocytes circulated in blood and lymph vessels also can be found in lymphoid tissue and lymphoid organ. One of the lymphoid organ is spleen. Spleen is a place for maintaining the mature naïve lymphocytes (Murphy \& Weaver, 2017). The spleen plays multiple supporting roles in the body. It acts as a filter for blood as part of the immune system. Old red blood cells are recycled in the spleen, and platelets and white blood cells are stored there. The spleen also helps fight certain kinds of bacteria. If spleen index is lower than normal, this indicates a mildly compromised immune system. This is usually an indication that spleen is not producing an adequate amount of red and white blood cells causing immune system to become weak. The spleen may also be enlarged due to viral or bacterial infections (Siddiqui \& Ali, 2015).

Spleen weight and spleen index may be changed in response to adaptive immunity. Spleen weight could be enhanced by the immune system activators. It has been reported that immunomodulator can enhance the spleen index in the mice exposed to cyclophosphamide (Zhao et al., 2015). Spleen index is ratio of spleen weights $(\mathrm{mg})$ and body weight $(\mathrm{kg})$. In the research conducted by Zhao et al. (2015), polysaccharides from Scissandra chinensis with low, medium and high doses could enhance spleen index compare with normal control and negative control groups.

This present result of spleen weight is presented in Figure 1. The highest spleen weight was shown by P3 group $(480 \pm 83.66 \mathrm{mg})$ and the lowest spleen weight was shown by $\mathrm{KN}$ group

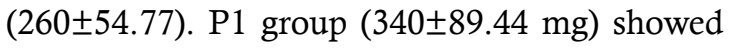
an increase of spleen weight but the difference was not statistically significant. Compared with $\mathrm{KN}$ and $\mathrm{K}$ - group, P2 group at dose of $50 \mathrm{mg}$ / $\mathrm{kg} \mathrm{BW}, \mathrm{P} 3$ group at dose of $75 \mathrm{mg} / \mathrm{kg} \mathrm{BW}$, and $\mathrm{P} 4$ group at dose of $100 \mathrm{mg} / \mathrm{kg} \mathrm{BW}$ have signifi- 
cantly increased the spleen weight $(p<0.05)$. Oral administration of okra polysaccharides at dose of 50,75 , and $100 \mathrm{mg} / \mathrm{kg} \mathrm{BW}$ increased spleen weight to $460 \pm 134.16 \mathrm{mg}, 480 \pm 83.66 \mathrm{mg}$, and $460 \pm 89.44 \mathrm{mg}$ respectively.

Similarly, study conducted by Chen et al. (2016) showed that highest dose of okra polysaccharides $(100 \mathrm{mg} / \mathrm{kg} \mathrm{BW})$ increased the spleen index significantly with cyclophosphamide as an antigen. Our present result suggested that okra polysaccharides enhance spleen weight and induce the increase in number of splenocytes in spleen. Rising number of splenocytes will be followed by increasing spleen weight.

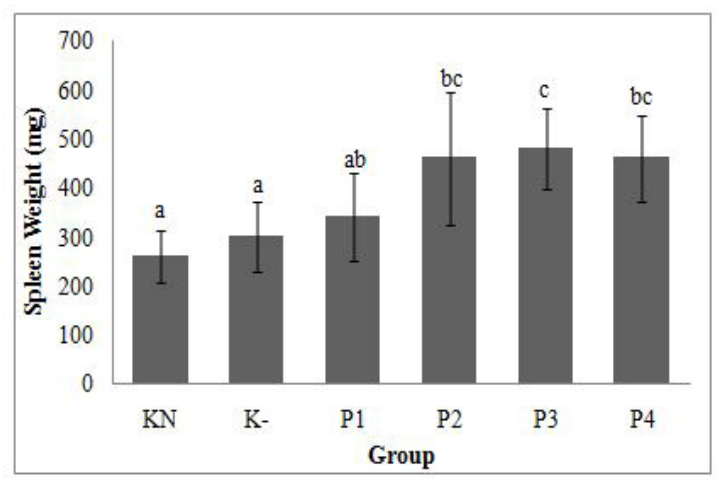

Figure 1. Effect of okra polysaccharides on spleen weight. Values are means \pm SD $(n=5)$. Different superscripts indicate a significance difference $(p<0.05)$.

The increase of spleen weight is a response to proliferation of spleen cell. Therefore, we investigated the effect of okra polysaccharides on B-lymphocytes proliferation placed in spleen. Splenocytes are immune cells found in spleen. Splenocytes consist of T-lymphocytes, B-lymphocytes, macrophages, and dendritic cells (Cho et al., 2015). The primary function of B-lymphocytes is the production of antibodies that are specific for a given antigenic component of an invading pathogen (O'Gorman \& Donnenberg, 2008). Blymphocytes mediate humoral immunity. Soluble antigens and antigens on the surface of $S$. aureus will bind to these B-lymphocytes antigen receptors and leads to the secretion of soluble form of antibodies (Abbas et al., 2010).

Polysaccharides regulate host immune system by activating immune-related cell such as lymphocytes, macrophages, and NK cells (Jiang $e t$ al., 2010). Activating one of immune components will result in the activation of other immune components including B-lymphocytes in spleen. This result of B-lymphocytes proliferation is presented in Figure 2. The highest B-lymphocytes proli- feration was shown by P3 group $(0.453 \pm 0.028)$ and the lowest B-lymphocytes proliferation was shown by $\mathrm{KN}$ group $(0.287 \pm 0.005)$. P1 group $(0.301 \pm 0.015)$ and $\mathrm{P} 2$ group $(0.321 \pm 0.033)$ showed slight increase of B-lymphocytes proliferation but did not statistically show difference. P3 group at dose of $75 \mathrm{mg} / \mathrm{kg} \mathrm{BW}$ and $\mathrm{P} 4$ group at dose of $100 \mathrm{mg} / \mathrm{kg}$ BW significantly increased spleen weight $(p<0.05)$ compared with $\mathrm{KN}$ group and K-group. Oral administration of okra polysaccharides at dose of 75 and $100 \mathrm{mg} / \mathrm{kg} \mathrm{BW}$ increased B-lymphocytes proliferation with value of $0.453 \pm 0.028$ and $0.444 \pm 0.014$ respectively.

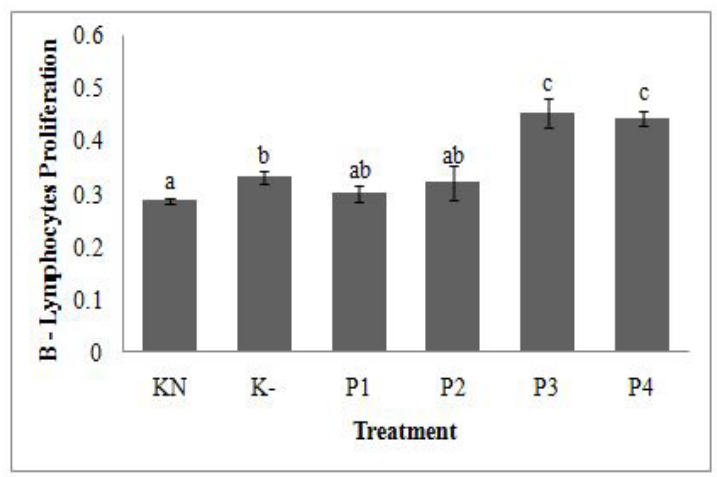

Figure 2. Effect of okra polysaccharides on Blymphocytes proliferation. Values are means \pm $\mathrm{SD}(\mathrm{n}=5)$. Different superscripts indicate a significance difference $(p<0.05)$.

Similar with study conducted by Zha et al. (2014), Dendrobium huoshananse polysaccharides at doses of 50,100, and $200 \mathrm{mg} / \mathrm{kg} \mathrm{BW}$ increased splenocyte proliferation of $140 \%, 165 \%$, and 196\% respectively. Chen et al. (2016) also revealed that administration of okra polysaccharides at doses of 25,50 , and $100 \mathrm{mg} / \mathrm{kg}$ BW significantly increase splenocyte proliferation induced by LPS and okra polysaccharide at dose of 100 $\mathrm{mg} / \mathrm{kg}$ BW showed highest rising of splenocyte proliferation. We can state that higher doses of polysaccharides help in rising the proliferation of B-lymphocytes. In line with our result, Wang et al. (2014) stated that splenocyte proliferation is related with improvement of T- or B-lymphocytes immunity which could be indicator of immune activation.

Increase proliferation of B-lymphocytes and spleen weight are affected by other immune-related cells. Zheng et al. (2014) stated that polysaccharides induces NO and cytokine production from the RAW264.7 cells through the activation of transcription factor NFкB. Transcription factor $\mathrm{NF} \kappa \mathrm{B}$ regulates many important biological and pathological processes and modu- 
lating the transcription of a large number of genes involving iNOS, IL and TNF- $\alpha$. Cytokines such as IL and TNF- $\alpha$ are produced by macrophages, T helper cells and NK cells (Detrick et al., 2008). Cytokine activation can be indicator of immunerelated cell activation. Immune-related cells such as macrophages, T-lymphocytes, and B-lymphocytes are also found in spleen. We can state that polysaccharides may induce cytokine production that activate immune-related cell in blood vessel and spleen. Activation of immune-related cells will be followed by proliferation of immune-related cells, including B-lymphocytes. Increasing of B-lymphocytes proliferation contributes on rising of spleen weight.

There is a positive correlation between spleen weight and B-lymphocytes by $73.3 \%$. It showed that when the weight of the spleen was large, the spleen cells also actively divided. Polysaccharides are a type of macromolecules with complicated structure. This complicated structure can affect their biological activity in immunerelated cells and their immunoregulatory activity (Zhao et al., 2014). Immunomodulatory activities of polysaccharides may be due to direct or indirect interaction with immune system component. Complement proteins, monocytes, macrophages, dendritic cells, neutrophils, and lymphocytes have been reported as target responding to polysaccharides (Schepetkin \& Quinn, 2006; Leung et al., 2006, Ramesh et al., 2002). A direct stimulatory effect on these immune cells involves specific recognition receptor. Upon binding of polysaccharides to specific recognition receptors on immune cells, diverse signaling pathway may be triggered, leading to response (Ferreira et al., 2015).

This present study revealed that okra polysaccharides may act as immunomodulator by enhancing B-lymphocytes proliferation and spleen weight. Okra polysaccharide can be an alternative food that provides health and medical benefits in addition to the basic nutritional value found in foods. Okra polysaccharides will help body to defense against bacteria including $S$. aureus. By introducing okra consumption in Indonesia, it was expected to suppress prevalence of nosocomial infection.

\section{CONCLUSION}

Based on the result presented above, we could conclude that administration of polysaccharides from okra (Abelmoschus esculentus) significantly increased the spleen weight and Blymphocytes proliferation. The optimum doses were 75 and $100 \mathrm{mg} / \mathrm{kg} \mathrm{BW}$. There was $73.3 \%$ positive correlation between spleen weight and B-lymphocytes proliferation. It proved that okra polysaccharide enhanced the immune response in spleen. These results suggest that okra polysaccharides could be utilized as a novel nutraceutical due to its effective immunomodulatory activity.

\section{ACKNOWLEDGEMENT}

This study was financially supported by applied research of pre-eminent college or Penelitian Terapan Unggulan Perguruan Tinggi (PTUPT), fiscal year 2017, No. 004/SP2H/LT/ DRPM/IV/2017, April $8^{\text {th }} 2017$.

\section{REFERENCES}

Abbas, A. K., Litchmann, A. H. \& Pober J. S. (2010). Cellular and molecular immunology. W. B. Saunders Company. Philadelphia.

Arapitsas, P. (2008). Identification and quantification of polyphenolic compounds from okra seeds and skins. Food Chemistry, 110(4), 1041-1045.

Battino, M., Bullon, P., Wilson, M., \& Hewman, H. (1999). Oxidative injury and inflammatory periodontal disease: the challenge of antioxidants to free radicals and reactive oxygen species. Critical Reviews in Oral Biology \& Medicine, 10(4), 458-476.

Bhowmik, D., Gopinath, H., Kumar, B. P., Duravei, S., \& Kumar, K. P. S. (2012). Nutraceutical-a bright scope and opportunity of Indian healthcare market. The Pharma Innovation, 1(11), 2941.

Chen, H., Jiao, H., Cheng, Y., Xu, K., Jia, X., Shi, Q. Guo,S., Wang, M., Du, L. \& Wang, F. (2016). In vitro and in vivo immunomodulatory activity of okra (Abelmoschus esculentus L.) Polysaccharides. Journal of Medical Food, 19(3), 253265.

Cho, C. W., Han, C. J., Rhee, Y. K., Lee, Y. C., Shin, K. S., Shin, J. S., Lee, K. T. \& Hong, H. D. (2015). Cheonggukjang polysaccharides enhance immune activities and prevent cyclophosphamide-induced immunosuppression. International Journal of Biological Macromolecules, 72, 519-525.

O'Gorman, M. R. G. \& Donnenberg, A. D. (2008). Handbook of human immunology second edition. CRC Press Taylor and Francis Group. New York.

D’Elios, M. M., Benagiano, M., Bella, C. D. \& Amedei, A. (2011). T-cell response to bacterial agent. Journal of Infected Development Countries, 5(9), 640-645.

Detrick, B., Nagineni, C. N., \& Hook, J. (2008). Cytokines: regulators of immune responses and key therapeutic targets. Handbook of Human Immunology. CRC Press. New York.

Diekema, D. J., Pfaller, M. A., Schmitz, F. J., 


\section{Sri Puji Astuti Wahyuningsih et al. / Biosaintifika 9 (3) (2017) 460-465}

Smayevsky, J., Bell, J., Jones, R. N., \& Beach, M. (2001). Survey of infection due to Staphylococcus species: frequency of occurance and antimicrobial suspectibility of isolates collected in the United States, Canada, Latin America, Europe, and the Western Pacific region for the SENTRY Antimicrobial Surveillance Program, 1997-1999. Clinical Infectious Diseases, 15(32), S114-S132.

Ferreira, S. S., Passos, C. P., Madureira, P., Vilanova, M. \& Coimbra, M. (2015). A structure function relationships of immunostimulatory polysaccharides: a review. Carbohydrates Polymers, 132, 378-396.

Jiang, M. H., Zhu, L. \& Jiang, J. G. (2010). Immunoregulatory actions of polysaccharides from Chinese herbal medicine. Expert Opinion Theriology Targets, 14(12), 1367-1402.

Khatun, H., Rahman, A., Biswas, M. \& U1 Islam, A. (2011). Water soluble fraction of Abelmoschus esculentus $\mathrm{L}$ interacts with glucose and metformin hydrochloride and alters their absorbtion kinetics after co-administration in rats. ISRN Pharmaceutics, 2011, 1-5.

Lengsfeld, C., Titgemeyer, F., Faller, G. \& Hensel A. (2004). Glycosylated compounds from okra inhibit adhesion of Helicobacter pylori to human gastric mucosa. Journal of Agricultural and Food Chemistry, 52(6), 1495-1503.

Leung, M. Y. K., Liu, C., Koon, J. C. M. \& Fung, K. P. (2006). Polysaccharide biological response modifiers. Immunology Letters, 105(2), 101-114.

Lim, T. K. (2012). Edible Medicinal and Non-Medicinal Plants Volume 3. Springer Science Business Media B.V. New York.

Lin, Y. C. \& Peterson, M. L. (2010). New insight into the prevention of staphylococcal infections and toxic shock syndrome. Expert Review of Clinical Pharmacology, 3(6), 753-767.

Moyin-Jesu, E. I. (2007). Use of plant residues for improving soil fertility, pod nutrients, root growth, and pod weight of okra (Abelmoschus esculentus L.). Bioresource technology, 98(11), 2057-2064.

Murphy, K. \& Weaver, C. (2017). Janeway's Immunology $9^{\text {th }}$ Edition. Garland Science. Taylor \& Francis Group. New York.

Nadira, S., Hatidjah, B., \& Nuraeni. (2009). Pertumbuhan dan Hasil Tanaman Okra (Abelmoschus esculantus) pada Perlakuan Pupuk Dekaform dan Defoliasi. Jurnal Agrisains, 10(1), 10-15.

Naveed, A., Khan, A. A. \& Khan, I. A. (2009). Generation mean analysis of water stress tolerance in okra (Abelmoschus esculentus L). Pakistan Journal of Botany, 41(1), 195-205.
Ramesh, H. P., Yamaki, K., Tsushida, T. (2002). Effect of fenugreek (Trigonella foenum-graecum $\mathrm{L}$.) galactomannan fractions on phagocytosis in rat macrophages and on proliferation and IgM secretion in HB4C5 cells. Carbohydrate Polymers, 50(1), 79-83.

Schepetkin, I. A. \& Quinn, M. T. (2006). Botanical polysaccharides: Macrophage immunomodulation and therapeutic potential. International Immunopharmacology, 6(3), 317-333.

Schito, G. C. (2006). The importance of the development of antibiotic resistence in Staphylococcus aureus. Clinical Microbial Infection, 12(1), 3-8.

Sheu, S. C. \& Lai, M. H. (2012). Composition analysis and immune-modulatory effect of okra (Abelmoschus esculentus) extract. Food Chemistry, 134(4), 1906-1911.

Siddiqui, M. A. \& Ali, A. H. A. (2015). Assessment of normal spleen size. International Journal Pharmacy Biology Science, 6, 46-57.

Wahyuningsih, S. P. A., Savira, N. I. I. \& Darmanto, W. (2016). Effect on polysaccharide krestin from Coriolus versicolor extract on phagocytic activity and capacity of Mus musculu sexposed by Pseudomonas aeruginosa. Biosaintifika: Journal of Biology \& Biology Education, (8)3, 308-313.

Wang, N., Yang, J., Lu, J., Qiao, Q., Wu, T., Du, X., Bao, G. \& He, X. (2014). A polysaccharides from Salvia miltiorrhiza bungee improves immune function in gastric cancer rats. Carbohydrate Polymers, 111, 47-55.

World Health Organization. (2012). The burden of health-care-associated infection worldwide. Retrieved from www.who.int

Zha, X. Q., Zhao, H. W., Bansal, V., Pan, L. H., Wang, Z. M. \& Luo, J. P. (2014). Immunoregulatory activities of Dendrobium huoshananse polysaccharides in mouse intestines, spleen and liver. International Journal of Biological Macromolecules, 64, 377-382.

Zhao, T., Feng, Y., Li, J., Mao, R., Zou, Y., Feng, W., Zheng, D., Wang, W., Chen, Y., Yang, L. \& Wu, X. (2014). Scisandra polysaccharides evokes immunomodulatory activity through TLR 4-mediated activation of macrophages. International Journal of Biological Macromolecules, 65, 33-40.

Zheng, W., Zhao, T., Feng, W., Wang, W., Zou, Y., Zheng, D., Takase, M., Li, Q, Wu, H, Yang, L. \& Wu X. (2014). Purification, characterization and immunomodulating activity of a polysaccharide from flowers of Abelmoschus esculentus. Carbohydrate Polymers, 106, 335-342. 